\title{
Isothermal Kinetic Analysis of the Thermal Decomposition of Wood Chips from an Apple Tree
}

\author{
Ivan Vitázek ${ }^{1}$ (), Martin Šotnar ${ }^{2}$, Stella Hrehová ${ }^{3, *}$, Kristína Darnadyová $^{4}$ and Jan Mareček $^{2}$ \\ 1 Department of Transport and Handling, Faculty of Engineering, Slovak University of Agriculture in Nitra, \\ Tr. A. Hlinku 2, 94976 Nitra, Slovak; ivan.vitazek@uniag.sk \\ 2 Department of Agricultural, Food and Environmental Engineering, Faculty of Agronomy, \\ Mendel University in Brno, Zemědělská 1, 61300 Brno, Czech Republic; martin.sotnar@mendelu.cz (M.Š.); \\ jan.marecek@mendelu.cz (J.M.) \\ 3 Department of Industrial Engineering and Informatics, Faculty of Manufacturing Technologies, \\ Technical University of Košice, Bayerova 1, 08001 Prešov, Slovak \\ 4 Central Control and Testing Institute in Agriculture, Letná 3, 04139 Košice, Slovak; \\ kristina.darnadyova@uksup.sk \\ * Correspondence: stella.hrehova@tuke.sk; Tel.: +421-55-602-6415
}

check for

updates

Citation: Vitázek, I.; Šotnar, M.; Hrehová, S.; Darnadyová, K.; Mareček, J. Isothermal Kinetic Analysis of the Thermal

Decomposition of Wood Chips from an Apple Tree. Processes 2021, 9, 195. https://doi.org/10.3390/pr9020195

Received: 23 October 2020

Accepted: 19 January 2021

Published: 21 January 202

Publisher's Note: MDPI stays neutral with regard to jurisdictional claims in published maps and institutional affiliations.

Copyright: (c) 2021 by the authors. Licensee MDPI, Basel, Switzerland. This article is an open access article distributed under the terms and conditions of the Creative Commons Attribution (CC BY) license (https:// creativecommons.org/licenses/by/ $4.0 /)$.

\begin{abstract}
The thermal decomposition of wood chips from an apple tree is studied in a static air atmosphere under isothermal conditions. Based on the thermogravimetric analysis, the values of the apparent activation energy and pre-exponential factor are $34 \pm 3 \mathrm{~kJ} \mathrm{~mol}^{-1}$ and $391 \pm 2 \mathrm{~min}^{-1}$, respectively. These results have also shown that this process can be described by the rate of the first-order chemical reaction. This reaction model is valid only for a temperature range of $250-290{ }^{\circ} \mathrm{C}$, mainly due to the lignin decomposition. The obtained results are used for kinetic prediction, which is compared with the measurement. The results show that the reaction is slower at higher values of degree of conversion, which is caused by the influence of the experimental condition. Nevertheless, the obtained kinetic parameters could be used for the optimization of the combustion process of wood chips in small-scale biomass boilers.
\end{abstract}

Keywords: wood chips; apple tree; thermogravimetric analysis; kinetic analysis

\section{Introduction}

Nowadays, all kinds of human activity are directly or indirectly related to the use of different types of energy. With the rise of living standards and the rise of the world population, the overall energy demand in the world is still growing. Global environmental issues and the extraction of fossil fuels pose serious problems for energy consumption. Environmentally friendly energy technologies and the transition to non-fossil resources of energy, such as renewable energy sources, are expected, and seem to be very promising.

Apple trees are important crops, accounting for the production of more than 80 million tons worldwide [1,2]. They are commonly grown in various regions where the climate is particularly favourable for fruit quality [2]. Fruit trees also have natural enemies, including parasitoids, predators, and pathogens [3]. Therefore, the infected trees can be used as a renewable energy source, for example in small-scale biomass boilers. However, to use the woody biomass as an energy source, it is necessary to use it rationally and in a sustainable way [4-6]. On the other hand, there are still some problems in current biomass combustion furnaces, but where a kinetic analysis is a suitable tool to solve them $[7,8]$.

Various studies [9-15] observed that the region of the thermal decomposition of the main wood constituents, such as hemicelluloses, cellulose, and lignin, can be divided into two steps. The first point of view states that in the temperature range of $\sim 200-400{ }^{\circ} \mathrm{C}$, the combination of total hemicellulose and cellulose decomposition with partial lignin decomposition occurs. The second step could be described as the decomposition of the remaining lignin and the combustion of char residues $[9,10]$. The reason why lignin 
decomposes slowly under the whole thermal decomposition temperature range is that it contains an aromatic matrix, which itself increases the degree of the condensation reaction [16-18]. Decomposition of lignin from different origins were observed in the study by Brodin et al. [19] and the conclusion is that the loss of $\sim 40 \%$ took place in the temperature range $200-600{ }^{\circ} \mathrm{C}$, with a maximum in material loss at $\sim 400{ }^{\circ} \mathrm{C}$.

On the other hand, the overall thermal decomposition and the reaction behaviour depends on the elementary constituents. These processes have been studied on several types of biomass; however, for apple tree biomass, it should be described more precisely [20].

The studies [11-15] also assumed a two-step process, were the first step can be described as volatilization of the main constituents and the second step can be characterized as combustion of the char residue. Along with that, an interaction between the components during the thermal decomposition may occur under certain conditions [21-23]. Due to the complex composition and structure of lignocellulosic materials, the thermal decomposition could be affected by various factors. For more information regarding these factors, we recommended some of the previous studies. We would like to note that mainly the chemical composition, particle size, and isothermal regime influence the thermal decomposition kinetics $[12,14,24,25]$.

Numerous research studies have been performed in order to determine the kinetic triplet (activation energy, pre-exponential factor, and reaction model) of the processes that occurs during thermal treatment of various woody biomass. In the case of the reaction model, it is generally assumed that the first-order reaction $(f(\alpha)=(1-\alpha))$, where $\alpha$ stands for a degree of conversion, is suitable for the description of the thermal decomposition of various kinds of woody biomass [15]. On the other hand, some studies [26-29] use the reaction order model $\left(f(\alpha)=(1-\alpha)^{n}\right)$, where $n$ is the reaction order. Another approach was used in $[13,14]$, where the thermal decomposition was divided into two separated reactions and each of them was also described by the first-order reaction model.

This study focuses on the kinetic analysis of the thermal decomposition of woody biomass from an apple tree. Thermogravimetric (TG) analysis, which can provide the information about the mass loss of the sample during heating, was used to obtain the data for the kinetic analysis, from which the values of the Arrhenius parameters, i.e., apparent activation energy and pre-exponential factor, were calculated. In addition, the most probable reaction model was determined. Biomass is a substance of biological origin that includes plant biomass grown in soil and water, animal biomass, organic production, and organic waste. It is expected to replace a significant part of non-renewable conventional energy sources in the future. Therefore, these results were subsequently used for kinetic prediction of thermal decomposition. The authors also believe that such a study will contribute to the development of efficient biomass combustion applications. Note that this study is a continuation of a previous research study dealing with the kinetic analyses of woody biomass, by the same authors [4].

\section{Materials and Methods}

The wood chips used in this study came from an apple tree growing in the locality of Nitra, Slovakia (see Figure 1). The image of the surface of the wood chips, magnified $80 \times$, is shown in Figure 1b. The content of the lignin and cellulose in the samples was determined by using an Ankom Fiber Analyzer A200 (Macedon, NY, USA), where the presented value is an average of three measurements. 


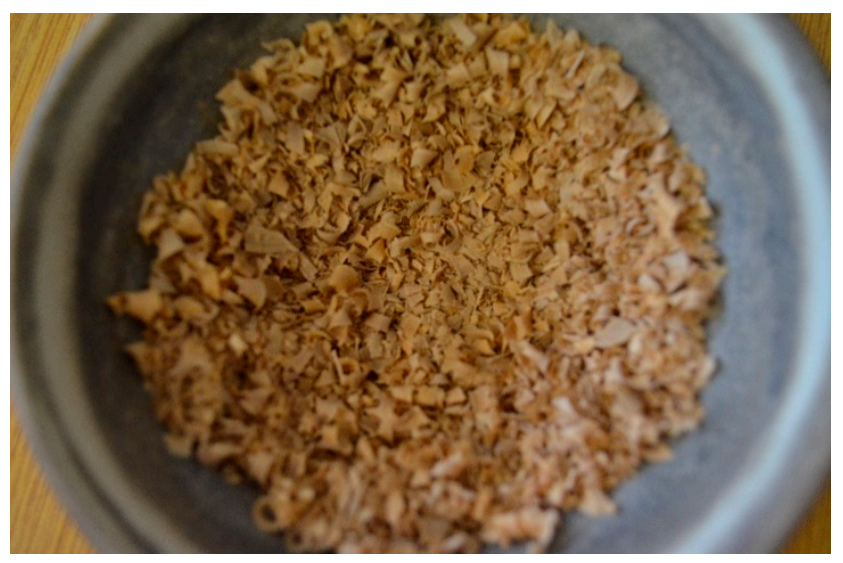

(a)

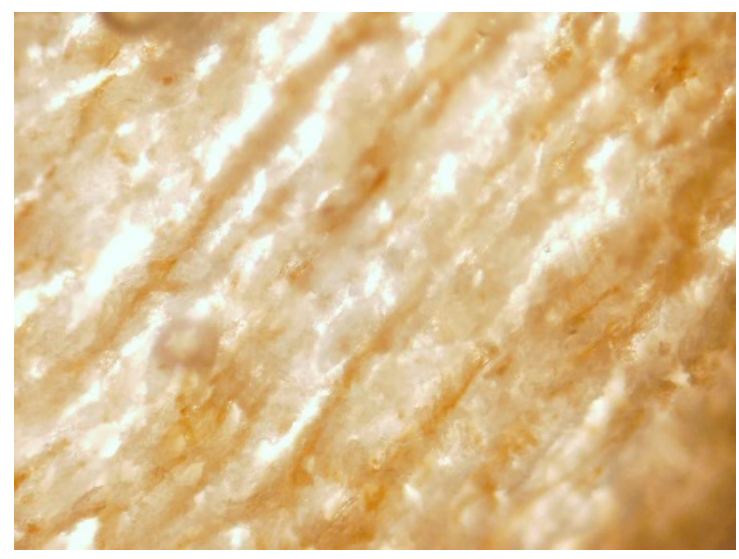

(b)

Figure 1. (a) Wood chips used in this study, and (b) image of the surface of the wood chips (magnification of $80 \times$ ).

Harvested wood was chopped into $5-10 \mathrm{~cm}$ pieces and grinded with a mill. Fractions between $0.5-2 \mathrm{~mm}$ were collected by sieving and used as feedstock for the subsequent thermogravimetric analysis.

The thermogravimetric measurements were carried out by using a Nabertherm L9/11/SW/P330 (Nabertherm GmbH, Lilienthal, Germany) furnace with a P330 Controller. Thermocouple type $S$ was used to measure the temperature inside the furnace near the sample-from an appropriate distance-to ensure that the measurement was not affected by exothermic reactions. For the measurement of the mass loss, the Kern EG 220 digital scales were connected to a personal computer using the RS232 interface, and data were measured every $30 \mathrm{~s}$ simultaneously with the temperature. Moreover, a static air atmosphere and samples of $\sim 5 \mathrm{~g}$ in mass were used. This apparatus (Figure 2) was chosen due to the possibility of measuring samples with masses that approach industrial applications. It is well known that thermogravimetry is commonly used for kinetic analysis, where the samples with smaller masses are usually used. However, samples with higher masses were used for the measurements, assuming the possible industrial application of the biomass, as is described in the EN ISO 17225:2014 standard for solid biofuels. In addition, using samples of $\sim 5 \mathrm{~g}$ can reveal the influence of a temperature gradients during the thermal processes.

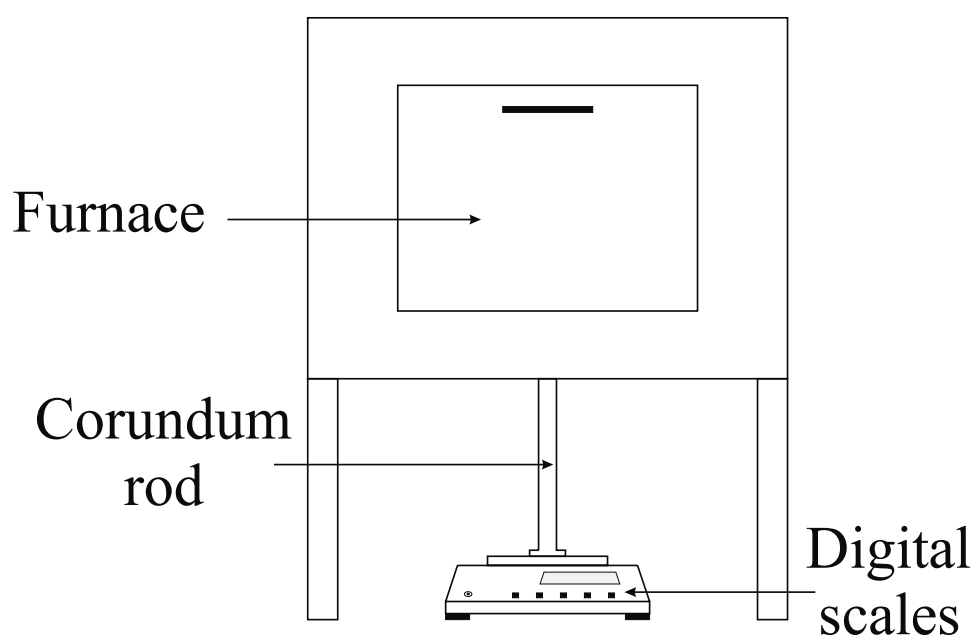

Figure 2. The apparatus used in this study.

Non-isothermal thermogravimetric analyses were used to describe the processes occurring during the heating of the woody biomass in the temperature range of $25-900{ }^{\circ} \mathrm{C}$, with a heating rate of $5^{\circ} \mathrm{C} \mathrm{min}^{-1}$. The numerical derivation of the TG curve provides the 
dTG curve. In the case of isothermal measurements, the heating rate of $10^{\circ} \mathrm{C} \mathrm{min}^{-1}$ was used to reach the isothermal temperatures of $250{ }^{\circ} \mathrm{C}, 270{ }^{\circ} \mathrm{C}$, and $290^{\circ} \mathrm{C}$. Moreover, this heating rate was used to minimize the impact of the thermal decomposition on the results before we reached the isothermal temperature. All experiments were carried out under a given condition more than twice in order to ensure reproducibility and reliability of the obtained results.

Kinetic Analysis

The thermal decomposition of woody biomass is often expressed as follows [26]:

$$
\text { Wood } \stackrel{k(T)}{\rightarrow} \text { Char }+ \text { Volatiles, }
$$

where $k(T)$ is the rate constant $\left(\mathrm{s}^{-1}\right)$ and Volatiles characterize the sum of the gas and tar. The rate of the reaction can be described by the following equation [30,31]:

$$
\frac{\mathrm{d} \alpha}{\mathrm{d} t}=k(T) f(\alpha)
$$

where $t$ is time (s), $T$ is the absolute temperature $(\mathrm{K})$, and $f(\alpha)$ characterized the reaction model. The temperature dependence of the rate constant is commonly described by the Arrhenius equation [30-32]:

$$
k(T)=A \exp \left(-\frac{E}{R T}\right),
$$

where $A$ and $E$ are the Arrhenius parameters (pre-exponential factor and activation energy, respectively), $R$ is the universal gas constant and $T$ is the thermodynamic temperature. In the case of the thermogravimetric experiments, the degree of conversion can be calculated using the following equation [33]:

$$
\alpha=\frac{m_{i}-m}{m_{i}-m_{f}}
$$

where $m$ is current, $m_{i}$ initial, and $m_{f}$ the final value of the sample mass. Equation (2) can be written in the integral form [34],

$$
g(\alpha)=k(T) t
$$

where $g(\alpha)$ is the integral form of a reaction model. Dependence of the $g(\alpha)$ on the time must give a straight line for the proper reaction model, where the slope of this plot corresponds to the $k(T)$. The models used in this study are listed in Table 1.

Table 1. The kinetic models used in this study $[29,34]$.

\begin{tabular}{ccccc}
\hline No. & Code & Reaction Model & $f(\alpha)$ & $g(\alpha)$ \\
\hline 1. & F1, A1 & Mampel (first-order) & $(1-\alpha)$ & $-\ln (1-\alpha)$ \\
2. & F2 & Second-order & $(1-\alpha)^{2}$ & $(1-\alpha)^{-1}-1$ \\
3. & F3 & Third-order & $(1 / 2)(1-\alpha)^{3}$ & $(1-\alpha)^{-2}-1$ \\
\hline
\end{tabular}

The determination of Arrhenius parameters $A$ and $E_{a}$ is based on the logarithmic form of Equation (3) $[29,35,36]$ :

$$
\ln k(T)=\ln A-\frac{E_{a}}{R T},
$$

where the slope of the plot of the left-hand side vs. $T^{-1}$ is equal to $-E_{a} / R$ and the intercept with $y$-axis is equal to the $\ln A$. Note that the apparent activation energy $E_{a}$ is a value that characterizes the combination of several processes. 


\section{Results and Discussion}

The measured samples contained $\sim 15 \%$ lignin, $\sim 49 \%$ cellulose, and $\sim 32 \%$ hemicellulose. The occurrence of several processes during the thermal treatment is clearly visible in Figure 3, where the non-isothermal TG and dTG curves for the heating rate of $5{ }^{\circ} \mathrm{C} \mathrm{min}^{-1}$ are shown. According to the various studies (see Section 1), the first peak on the dTG curve in the temperature range of $30-150{ }^{\circ} \mathrm{C}$ can be attributed to the elimination of the humidity. During this step, the mass loss is $\sim 5 \mathrm{wt} . \%$. The second peak (the main decomposition region), occurring in the temperature range of $200-350{ }^{\circ} \mathrm{C}$ and with a mass loss of $\sim 60 \mathrm{wt} . \%$, corresponds to the volatilization of the main constituents. This assumption is based on isothermal measurements [11], where due to the slower decomposition of lignin, different heating rates could lead to different explanations of the measurements. The last peak on the dTG curve, in the temperature range of $350-500{ }^{\circ} \mathrm{C}$, is linked to the combustion of the char residues [37].

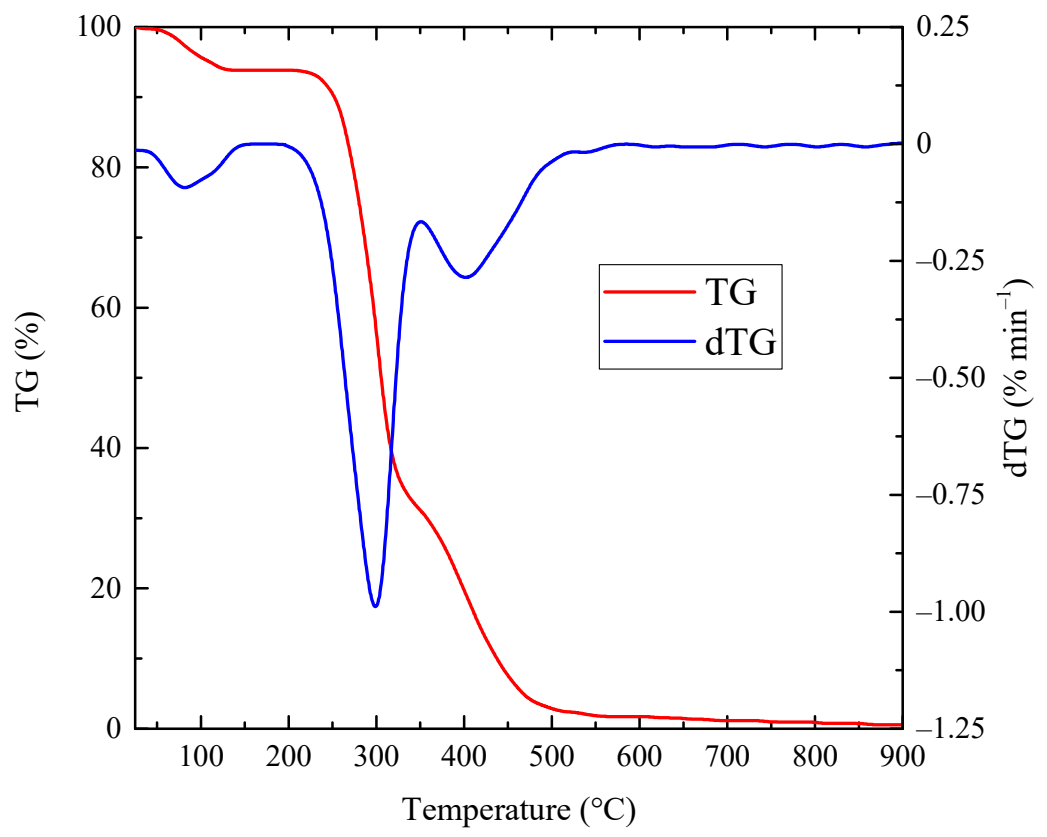

Figure 3. TG and dTG curves for the non-isothermal measurements with a heating rate of $5{ }^{\circ} \mathrm{C} \min ^{-1}$.

Based on these results, the isothermal thermogravimetric analyses were carried out using the temperatures $250^{\circ} \mathrm{C}, 270^{\circ} \mathrm{C}$, and $290^{\circ} \mathrm{C}$, which correspond to the main decomposition region. These temperatures were also chosen due to the expectation that the lignin does not fully decompose at lower than $300{ }^{\circ} \mathrm{C}$ [11]. This is due to the assumption that it is hard to correctly determine the apparent activation energy and pre-exponential factor of the reaction in the region of lignin decomposition. The results of the thermogravimetric analysis with the corresponding conversion curves calculated according to Equation (4) are shown in Figure 4. 


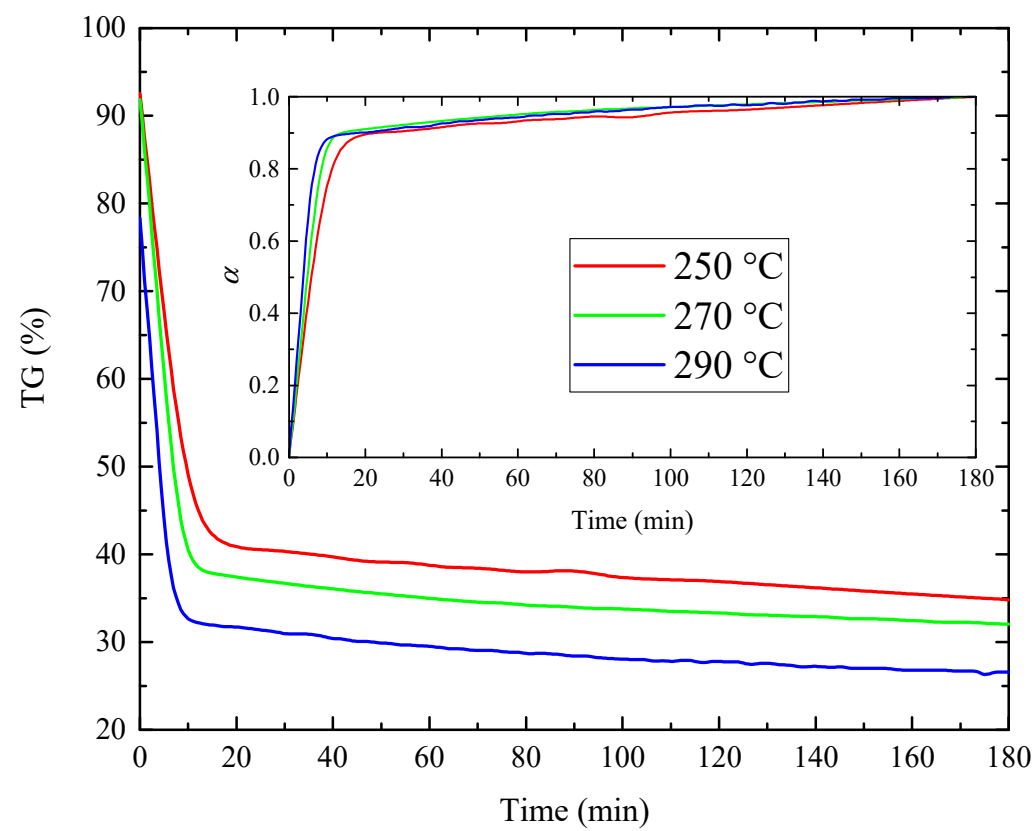

Figure 4. Results of TG analysis under isothermal heating. Inserted graph: dependence of the conversion degree on the time.

\subsection{Kinetic Analysis}

For the determination of the most probable reaction mechanism via linearization, the $\alpha=f(t)$ dependence must be transformed into the $g(\alpha)=f(t)$ function, which depends on the process of the reaction [38]. The dependence of $g(\alpha)$ on time must give a straight line for a proper reaction model, where the slope corresponds to the $k(t)$. In this study, the values of the rate constant were calculated for a conversion degree in the range of $0.10 \leq \alpha \leq 0.85$. The results show that the best model for this process, which represents the measured data most accurately, is the first-order reaction (F1). The $\mathrm{R}^{2}$ values calculated for the different reaction models are listed in Table 2 . This is in agreement with the previously published results by Liu et al. [15] and Vitázek and Tkáč [37]. In both studies, the kinetic analyses show that if the first-order reaction model (see Table 1) is used, the best final fit of the Arrhenius function is achieved. On the other hand, the determined reaction model could not describe the whole decomposition region due to the lignin decomposition.

Table 2. Determination of the most probable mechanism of thermal decomposition based on the $\mathrm{R}^{2}$ calculation.

\begin{tabular}{ccccc}
\hline \multirow{2}{*}{ Code } & Reaction Model & \multicolumn{3}{c}{ Temperature $\left({ }^{\circ} \mathrm{C}\right)$} \\
\cline { 2 - 5 } & & $\mathbf{2 5 0}$ & $\mathbf{2 7 0}$ & $\mathbf{2 9 0}$ \\
\hline F1 & Mampel (the first-order) & $\mathbf{0 . 9 9 5 6}$ & $\mathbf{0 . 9 8 7 4}$ & $\mathbf{0 . 9 9 1 9}$ \\
F2 & Second-order & 0.9273 & 0.8937 & 0.9288 \\
F3 & Third-order & 0.8061 & 0.7546 & 0.8184 \\
\hline
\end{tabular}

The determined $\ln (k)$ values were used for the determination of the apparent activation energy and pre-exponential factor (see Table 3). The pertinent kinetic parameters were determined from the Arrhenius-type plot (Figure 5), where the calculated values of $E_{a}$ and $A$ are $(34 \pm 3) \mathrm{kJ} \mathrm{mol}^{-1}$ and $(391 \pm 2) \mathrm{min}^{-1}$, respectively. 
Table 3. Determined values of $\ln (k)$.

\begin{tabular}{cc}
\hline Temperature $\left({ }^{\circ} \mathbf{C}\right)$ & $\ln (\boldsymbol{k})$ \\
\hline 250 & -1.87 \\
270 & -1.54 \\
290 & -1.32 \\
\hline
\end{tabular}

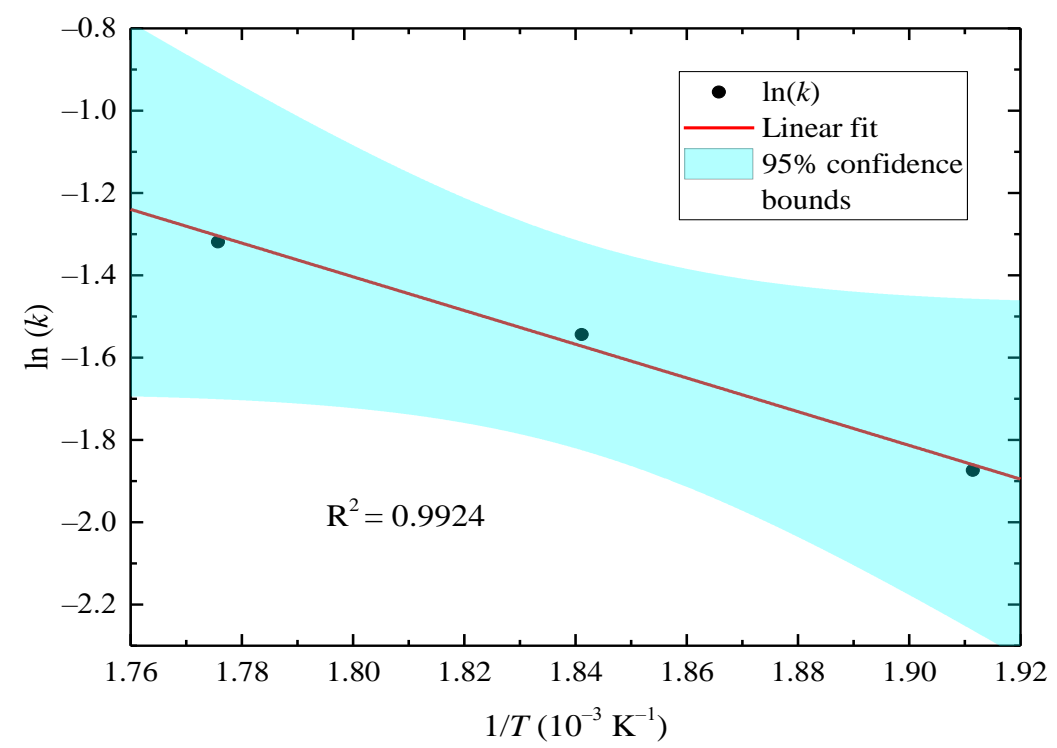

Figure 5. Determination of the apparent activation energy based on the Arrhenius-type plot.

These results are also similar compared to apple tree leaves [7], where the decomposition region was divided into two steps, with the apparent activation energies of the first and second stage being $34.2 \mathrm{~kJ} \mathrm{~mol}^{-1}$ and $32.3 \mathrm{~kJ} \mathrm{~mol}^{-1}$, respectively. However, what makes the difference is that the authors from the study mentioned above used different experimental conditions, such as heating rate, reaction atmosphere, and particle size. Moreover, different methods of kinetic analysis were used. On the other hand, the value of $E_{a}$ is significantly lower than the values published by Cui et al. [39], where the authors used the apple tree sawdust. In this study, the authors have reached a similar curve measured under non-isothermal conditions, as shown in Figure 3. However, the values of the activation energy in this study are in the range of $115.08-160.17 \mathrm{~kJ} \mathrm{~mol}^{-1}$ and $120.02-159.39 \mathrm{~kJ} \mathrm{~mol}^{-1}$, as determined by the Kissinger-Akahira-Sunose and Flynn-Wall-Ozawa method, respectively. These differences could be explained by different experimental conditions, such as isothermal and non-isothermal heating, the atmosphere during the reaction and sample masses. In case of Arrhenius parameters, it is well known that its values depend on the reaction atmosphere, where the review of the obtained values for various agricultural residue case studies could be found in [31]. Besides, the results by Wachter et al. [40] show that in a dynamic atmosphere, the decomposition temperature peak can occur in a higher temperature range. However, it is worth noting that the reaction atmosphere used in this study is more realistic in the case of smaller biomass boilers.

The different content of cellulose, hemicellulose, and lignin also could lead to the significant differences in the values of the kinetic parameters [41]. Another explanation for the lower values of the apparent activation energy and pre-exponential factor could be that the whole process undergoes a variety of competitive reactions.

\subsection{Kinetic Prediction of the Thermal Decomposition Region}

As soon as the Arrhenius parameters and reaction model were determined, the prediction of the thermal decomposition of the wood chips from the apple tree can be made. In this study, the kinetic prediction was computed according to Equations (2) and (3) using the 
Runge-Kutta method with the following parameters: $E_{a}=34 \mathrm{~kJ} \mathrm{~mol}^{-1}, A=391 \mathrm{~min}^{-1}$, and $T=260^{\circ} \mathrm{C}$. This temperature was chosen due to its correspondence with the main decomposition region. Moreover, it is different than the temperatures used for the parametrization of the process. The same as in the reaction model, the first-order reaction was chosen. The comparison of the computed and measured curve is shown in Figure 6.

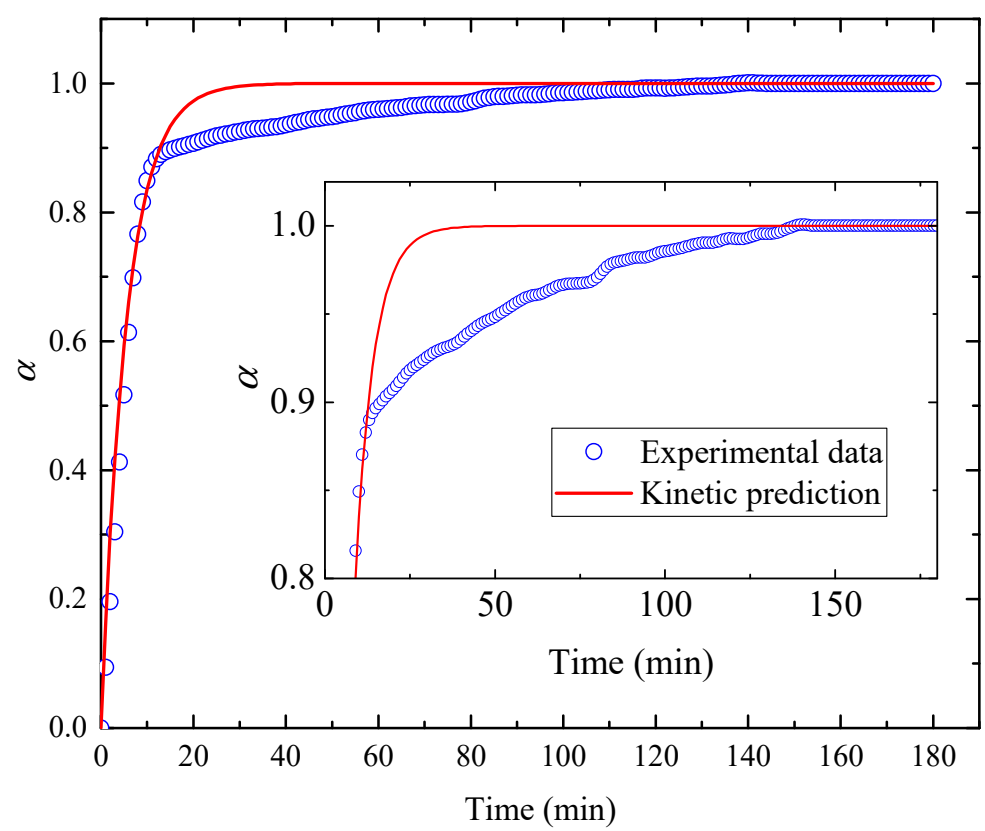

Figure 6. Kinetic prediction of the thermal decomposition of wood from an apple tree at a temperature of $260{ }^{\circ} \mathrm{C}$.

The comparison of the experimental and predicted curve shows the agreement of dependencies in the degree of conversion range of $0<\alpha<0.9$. On the other hand, in the region with higher values of $\alpha$, the reaction is slower than was predicted using the determined parameters. This behaviour can be explained by the influence of the experimental condition where the seemingly slight differences in certain processes vary, such as the particle size or heat transport, which can have a significant impact on the nature of the lignocellulosic decomposition reactions [31]. Nevertheless, the results could be used for the optimization of the combustion process of wood chips in small-scale biomass boilers. This can be concluded due to the fact that most of the input material (approximately $90 \%$ ) was decomposed during the first $\sim 10 \mathrm{~min}$.

\section{Conclusions}

A thermogravimetric analysis under a static air atmosphere was used to study the thermal decomposition of wood chips from an apple tree. The kinetic analysis was carried out using a conventional model-fitting method, where the apparent activation energy and pre-exponential factor were determined based on an Arrhenius-type plot. The summary of the results is as follows:

- The first-order reaction (F1) was determined as the most probable mechanism of the reaction. Due to the lignin decomposition, this reaction model was determined for a degree of conversion in the range of $0.10-0.85$.

- $\quad$ The determined values of $E_{a}$ and $A$ from the Arrhenius-type plot are $(34 \pm 3) \mathrm{kJ} \mathrm{mol}^{-1}$ and $(391 \pm 2) \mathrm{min}^{-1}$, respectively.

Based on these results, the kinetic prediction of the thermal decomposition region was produced, and the obtained curves were compared with the measurement. This comparison led to the finding that the seemingly slight differences in certain process can have a significant impact on the nature of the lignocellulosic decomposition reactions near 
the end of the process; this has a lot of implications for the modelling of such processes, and not only in the case of wood chips from an apple tree. Of course, the reaction model that was determined in this work cannot fully describe the whole process (mainly the last phases of the thermal decomposition), as it was also presented in various studies.

For a real application, such as the thermal decomposition of biomass in boilers, it is sufficient to vary the temperature in Equation (2) to obtain the reaction rate from which the mass loss during this process can be simply obtained.

We would like to note that we plan to study the thermal decomposition of a combination of various wood chips, such as with vineyard pruning residues, which is also important for development of effective combustion applications. So, these results will be used for studying the effects of adding various biodegradable materials, which is, however, beyond the scope of this paper.

Author Contributions: Methodology, I.V.; validation, K.D. and M.Š.; formal analysis, K.D.; investigation, I.V. and M.Š.; resources, J.M.; data curation, I.V. and S.H.; writing—original draft preparation, I.V.; writing-review and editing, M.Š.; visualization, M.Š.; supervision, J.M. and K.D.; project administration, S.H. and J.M.; funding acquisition, S.H. All authors have read and agreed to the published version of the manuscript.

Funding: This work was supported by the Slovak Research and Development Agency under the contract No. APVV-15-0602.

Data Availability Statement: Not applicable.

Acknowledgments: The research was supported by the Project of the Structural Funds of the EU, ITMS code 26220220103.

Conflicts of Interest: The authors declare no conflict of interest.

\section{References}

1. Food and Agriculture Organization of the United Nations. 2017. Available online: http://www.fao.org/news/archive/news-bydate/2017/en/ (accessed on 21 December 2017).

2. Nicola, L.; Turco, E.; Albanese, D.; Donati, C.; Thalheimer, M.; Pindo, M.; Insam, H.; Cavalieri, D.; Pertor, I. Fumigation with dazomet modifies soil microbiota in apple orchards affected by replant disease. Appl. Soil Ecol. 2017, 113, 71-79. [CrossRef]

3. Zhou, H.; Yu, Y.; Tan, X.; Chen, A.; Feng, J. Biological control of insect pests in apple orchards in China. Biol. Control 2014, 68, 47-56. [CrossRef]

4. Ondro, T.; Vitázek, I.; Húlan, T.; Lawson, M.; Csáki, Š. Non-isothermal kinetic analysis of the thermal decomposition of spruce wood in air atmosphere. Res. Agric. Eng. 2018, 64, 41-46.

5. Pitel', J.; Mižáková, J.; Hošovský, A. Biomass combustion control and stabilization using low-cost sensors. Adv. Mech. Eng. 2013, 5, 1-7. [CrossRef]

6. Mižáková, J.; Pitel', J.; Hošovský, A.; Kolarčík, M.; Ratnayake, M. Using special filter with membership function in biomass combustion process control. Appl. Sci. 2018, 8, 1279. [CrossRef]

7. Álvarez, A.; Pizarro, C.; García, R.; Bueno, J.L.; Lavín, A.G. Determination of kinetic parameters for biomass combustion. Bioresour. Technol. 2016, 216, 36-43. [CrossRef]

8. Khovanskyi, S.; Pavlenko, I.; Pitel, J.; Mizakova, J.; Ochowiak, M.; Grechka, I. Solving the coupled aerodynamic and thermal problem for modeling the air distribution devices with perforated plates. Energies 2019, 12, 3488. [CrossRef]

9. Safi, M.J.; Mishra, I.M.; Prasad, B. Global degradation kinetics of pine needles in air. Thermochim. Acta 2004, 412, 155-162. [CrossRef]

10. Orfão, J.J.M.; Antunes, F.J.A.; Figueiredo, J.L. Pyrolysis kinetics of lignocellulosic materials-Three independent reactions model. Fuel 1999, 78, 349-358. [CrossRef]

11. Vitázek, I.; Ondro, T.; Sunitrová, I.; Majdan, R.; Šotnar, M. Thermoanalytical investigation of selected fuel during isothermal heating. Agron. Res. 2019, 17, 2455-2459.

12. Bilbao, R.; Mastral, J.F.; Aldea, M.E.; Ceamanos, J. Kinetic study for the thermal decomposition of cellulose and pine sawdust in an air atmosphere. J. Anal. Appl. Pyrolysis 1997, 39, 53-64. [CrossRef]

13. Fang, M.X.; Shen, D.K.; Li, Y.X.; Yu, C.J.; Luo, Z.Y.; Cen, K.F. Kinetic study on pyrolysis and combustion of wood under different oxygen concentrations by using TG-FTIR analysis. J. Anal. Appl. Pyrolysis 2006, 77, 22-27. [CrossRef]

14. Shen, D.K.; Gu, S.; Luo, K.H.; Bridgwater, A.V.; Fang, M.X. Kinetic study on thermal decomposition of woods in oxidative environment. Fuel 2009, 88, 1024-1030. [CrossRef]

15. Liu, N.A.; Fan, W.; Dobashi, R.; Huang, L. Kinetic modeling of thermal decomposition of natural cellulosic materials in air atmosphere. J. Anal. Appl. Pyrolysis 2002, 62, 303-325. [CrossRef] 
16. Qiao, Y.; Wang, B.; Ji, Y.; Xu, F.; Zong, P.; Zhang, J.; Tian, Y. Thermal decomposition of castor oil, corn starch, soy protein, lignin, xylan, and cellulose during fast pyrolysis. Bioresour. Technol. 2019, 278, 287-295. [CrossRef]

17. Crestini, C.; Lange, H.; Sette, M.; Argyropoulos, D.S. On the structure of softwood kraft lignin. Green Chem. 2017, 19, 4104-4121. [CrossRef]

18. Ragauskas, A.J.; Beckham, G.T.; Biddy, M.J.; Chandra, R.; Chen, F.; Davis, M.F.; Davison, B.H.; Dixon, R.A.; Gilna, P.; Keller, M.; et al. Lignin valorization: Improving lignin processing in the biorefinery. Science 2014, 344, 1246843. [CrossRef] [PubMed]

19. Brodin, I.; Sjöholm, E.; Gallerstedt, G. The behavior of kraft lignin during thermal treatment. J. Anal. Appl. Pyrolysis 2010, 87, 70-77. [CrossRef]

20. Geršl, M.; Kanduč, T.; Matýsek, D.; Šotnar, M.; Mareček, J. The role of mineral phases in the biogas production technology. Ecol. Chem. Eng. S 2018, 25, 51-59. [CrossRef]

21. Hosoya, T.; Kawamoto, H.; Saka, S. Pyrolysis behaviors of wood and its constituent polymers at gasification temperature. J. Anal. Appl. Pyrolysis 2007, 78, 328-336. [CrossRef]

22. Hosoya, T.; Kawamoto, H.; Saka, S. Influence of inorganic matter on wood pyrolysis at gasification temperature. J. Wood Sci. 2007, 53, 351-357. [CrossRef]

23. Hosoya, T.; Kawamoto, H.; Saka, S. Cellulose-hemicellulose and cellulose-lignin interactions in wood pyrolysis at gasification temperature. J. Anal. Appl. Pyrolysis 2007, 80, 118-125. [CrossRef]

24. Pradhan, P.; Mahajani, S.M.; Arora, A. Production and utilization of fuel pellets from biomass: A review. Fuel Process. Technol. 2018, 181, 215-232. [CrossRef]

25. Holubčík, M.; Jandačka, J.; Kantová, N. Impact of the wood geometric parameters on the particulate matter production in small heat source. In Proceedings of the AIP Conference, Ho Chi Minh, Vietnam, 29-30 April 2018.

26. Slopiecka, K.; Bartocci, P.; Fantozzi, F. Thermogravimetric analysis and kinetic study of poplar wood pyrolysis. Appl. Energy 2012, 97, 491-497. [CrossRef]

27. Anca-Couce, A.; Zobel, N.; Berger, A.; Behrendt, F. Smouldering of pine wood: Kinetics and reaction heats. Combust. Flame 2012, 159, 1708-1719. [CrossRef]

28. TranVan, L.; Legrand, V.; Jacquemin, F. Thermal decomposition kinetics of balsa wood: Kinetics and degradation mechanisms comparison between dry and moisturized materials. Polym. Degrad. Stab. 2014, 110, 208-215. [CrossRef]

29. Harper, D.P.; Wolcott, M.P.; Rials, T.G. Evaluation of the cure kinetics of the wood/pMDI bondline. Int. J. Adhes. Adhes. 2001, 21, 137-144. [CrossRef]

30. Vyazovkin, S.; Burnham, A.K.; Criado, J.M.; Pérez-Maqueda, L.A.; Popescu, C.; Sbirrazzuoli, N. ICTAC Kinetics Committee recommendations for performing kinetic computations on thermal analysis data. Thermochim. Acta 2011, 520, 1-19. [CrossRef]

31. White, J.E.; Catallo, W.J.; Legendre, B.L. Biomass pyrolysis kinetics: A comparative critical review with relevant agricultural residue case studies. J. Anal. Appl. Pyrolysis 2011, 91, 1-33. [CrossRef]

32. Dhaundiyal, A.; Hanon, M.M. Calculation of Kinetic Parameters of the Thermal Decomposition of Residual Waste of Coniferous Species: Cedrus Deodara. Acta Technol. Agric. 2018, 21, 75-80. [CrossRef]

33. Vyazovkin, S.; Chrissafis, K.; Di Lorenzo, M.L.; Koga, N.; Pijolat, M.; Roduit, B.; Sbirrazzuoli, N.; Suñol, J.J. ICTAC Kinetics Committee recommendations for collecting experimental thermal analysis data for kinetic computations. Thermochim. Acta 2014, 590, 1-23. [CrossRef]

34. Vyazovkin, S.; Wight, C.A. Model-free and model-fitting approaches to kinetic analysis of isothermal and nonisothermal data. Thermochim. Acta 1999, 340-341, 53-68. [CrossRef]

35. Vlaev, L.; Nedelchev, N.; Gyurova, K.; Zagorcheva, M. A comparative study of non-isothermal kinetics of decomposition of calcium oxalate monohydrate. J. Anal. Appl. Pyrolysis 2007, 81, 253-262. [CrossRef]

36. Chien, Y.; Yang, T.; Hung, K.; Li, C.; Xu, J.; Wu, J. Effects of heat treatment on the chemical compositions and thermal decomposition kinetics of Japanese cedar and beech wood. Polym. Degrad. Stabil. 2018, 158, 220-227. [CrossRef]

37. Vitázek, I.; Tkáč, Z. Isothermal kinetic analysis of thermal decomposition of woody biomass: The thermogravimetric study. In Proceedings of the 38th Meeting of Departments of Fluid Mechanics and Thermodynamics, Chopok, Slovakia, 19-21 June 2019; AIP: Melville, NY, USA, 2019.

38. Ptáček, P.; Kubátová, D.; Havlica, J.; Brandštetr, J.; Šoukal, F.; Opravil, T. Isothermal kinetic analysis of the thermal decomposition of kaolinite: The thermogravimetric study. Thermochim. Acta 2010, 501, 24-29. [CrossRef]

39. Cui, X.; Yang, J.; Shi, X.; Lei, W.; Huang, T.; Bai, C. Experimental Investigation on the Energy Consumption, Physical, and Thermal Properties of a Novel Pellet Fuel Made from Wood Residues with Microalgae as a Binder. Energies 2019, 12, 3425. [CrossRef]

40. Wachter, I.; Hirle, S.; Balog, K. Thermal Properties of Lignocellulose Pellets. Res. Pap. Fac. Mater. Sci. Technol. Slovak Univ. Technol. 2017, 25, 83-90. [CrossRef]

41. Roberts, A.F. A review of kinetics data for the pyrolysis of wood and related substances. Combust. Flame 1970, 14, 261-272. [CrossRef] 